\title{
A rare case of hematuria
}

\author{
Um caso raro de hematúria
}

\author{
Andreia Mascarenhas ${ }^{1}$, Isabel Castro ${ }^{1}$
}

\section{ABSTRACT}

The infestation by Schistosoma haematobium is common in African countries and West Asia. Its chronic phase is characterized by the deposition of eggs of the parasite in various tissues of the body causing inflammatory response, formation of granulomas and fibrosis. The disease often affects the urinary tract, presenting with hematuria and, in the terminal stage, renal failure by urinary obstruction and bladder squamous neoplasia. Since chronic infection can lead to significant morbidity, it is imperative that the physicians who serve this immigrant population become familiar with this disease. A case of an immigrant boy from Guinea-Bissau seen in a Nephrology appointment for monosymptomatic terminal hematuria is presented. The diagnosis of urinary schistosomiasis was confirmed by parasitological examination of urine and the pathological examination of bladder biopsies. After therapy with praziquantel, the patient became asymptomatic.

Keywords: Hematuria; Schistosoma haematobium; Case reports

\section{RESUMO}

A infestação por Schistosoma haematobium é comum em países africanos e no oeste asiático. Sua fase crónica é caracterizada pela deposição de ovos do parasita em vários tecidos do organismo com resposta inflamatória, formação de granulomas e fibrose. Afecta frequentemente as vias urinárias, apresentando-se com hematúria, e, em fases terminais, com insuficiência renal por obstrução urinária e, em último caso, neoplasia escamosa da bexiga. Dado que a infecção crónica pode resultar em elevada morbilidade, é imperativo que os médicos que assistem essa população de imigrantes se familiarizem com tal doença. Apresentou-se aqui o caso clínico de uma criança natural da Guiné-Bissau observado em consulta de Nefrologia por hematúria terminal monossintomática. 0 diagnóstico de schistosomíase urinária foi confirmado por exame parasitológico da urina e pelo exame anatomopatológico das biópsias vesicais. Após terapêutica com praziquantel, o doente ficou assintomático.

Descritores: Hematuria; Schistosoma haematobium; Relatos de casos

\section{INTRODUCTION}

Schistosomiasis is an endemic parasitic disease in Africa, South America, Middle East, China, The Philippines and in some Caribbean islands. Approximately 200 million people in 74 countries are infected ${ }^{(1-2)}$. There are three species of Schistosoma that are relevant for human pathology: S. manson, S. japonicum and $S$. haematobium. The clinical presentation varies depending on the infecting species and S. haematobium is mainly responsible for urinary tract infection. In Europe, schistosomiasis remains as a rare cause of hematuria in children ${ }^{(3)}$. However, considering the close relation between Portugal and African countries (International Cooperation Agreement between Portugal and Portuguese Speaking African Countries), the differential diagnosis should always be considered in face of a child coming from that continent and presenting hematuria.

\section{CASE REPORT}

The authors presented a clinical case of a 10-year-old male child coming from Guinea-Bissau, who had been for 8 months in Portugal with the diagnosis of macroscopic hematuria and nephrotic syndrome. The family history comprised a paternal uncle with nonspecific renal disease. Since the age of 4 , he referred occasional episodes of monosymptomatic terminal macroscopic hematuria and facial edema of spontaneous resolution, with use of nonspecific therapy. He presented no other relevant past history.

In the visit to the pediatric nephrologist he showed general good status, weight $35.3 \mathrm{Kg}$ (P50-75), height 1.38 meters (P50-75) and blood pressure of 113/57 (complete blood count showed $12.7 \%$ eosinophilia), renal function and ionogram within normal range for

\footnotetext{
Study carried out at Hospital Dona Estefânia - HDE, Lisboa, Portugal.

1 Unit of Pediatric Nephrology, Hospital de Dona Estefânia - Centro Hospitalar Lisboa Central, EPE, Lisboa, Portugal.

Corresponding author: Andreia Mascarenhas - R. Jacinta Marto, 1169-045 Lisboa. - CEP 2750-611 - Lisboa, Portugal - 213126600. Fax: 213126667 - e-mail: amascarenhas22@yahoo.com

Received: Aug 14, 2010 - Accepted: Feb 15, 2011

Conflict of interest: none.
} 
age. Urine analysis showed $\mathrm{pH} 6$, density 1.017 , proteins $150 \mathrm{mg} / \mathrm{dL}$, hemoglobin +++ , leukocytes $25 \mathrm{mg} / \mathrm{dL}$, and sediments with many erythrocytes. Twelve-hour proteinuaria was $28 \mathrm{mg} / \mathrm{m}^{2} /$ hour. Uric acid, calcium, oxalate and 24-hour urinary phosphorus presented normal range for age. HIV-1 and HIV-2 serology and AgHBs were negative. The echogram showed right kidney with echogenic finding compatible with scar, bladder with echo in suspension and lobulated and vascularized wall thickness. To define the etiology, an urethrocystoscopy was performed and revealed trabeculated bladder with disperse, nodular, cottonlike and vascularized formations. Urine parasite test and bladder biopsies were positive for Schistosoma haematobium. Clinical pathology of renal biopsy showed abnormalities suggestive of segmental focal glomerulosclerosis.

After beginning therapy with praziquantel $(40 \mathrm{mg}$ / $\mathrm{kg}$ ) single dose there was resolution of hematuria. About six months later, he remained asymptomatic with normal urinary results and 12-hour proteinuria of $3.4 \mathrm{mg} / \mathrm{m}^{2} / \mathrm{h}$.

\section{DISCUSSION}

Urinary schistosomiasis is a serious public health problem in tropical countries and it is particularly common in Sub-Sahara Africa, resulting in high morbidity, especially in situations of chronic infection. It is estimated that about 200 million people are infected, out of which 88 million are aged less than 15 years ${ }^{(4)}$. The peak of incidence and prevalence occurs in schoolaged children, between 8 and 12 years ${ }^{(5)}$. Male gender is the most affected owing to greater recreational exposure to water ${ }^{(5)}$. Schistosoma haematobium is responsible for the infestation of the urinary tract leading to fibrosis, stenosis and calcification ${ }^{(1)}$. The life cycle of this parasite is complex and includes sexual reproduction of adult parasites in humans, in addition to a stage of asexual reproduction in the intermediate host, the fresh water snail Bulinus ${ }^{(6)}$. Infection in humans is acquired by direct contact with water that contains free larva forms (cercaria) released by the infected snails. Considering the preference for the venous plexus of the urinary tract, adult worms of $S$. haematobium live and lay their eggs there. The pathogenesis of the disease caused by this parasite is normally related with immune reactions of the body against the presence of the eggs in the tissues, which induce granulomatous inflammatory reactions ${ }^{(7)}$. Adult worms are recovered by host cells (many blood groups, major histocompatibility complex molecules, immunoglobulins and albumin), which mask their own antigens, escaping from the action of the immune system and they may continue to produce an incredible number of eggs for many years ${ }^{(8)}$. About 10 to 12 weeks after the contact with the parasite, there is terminal or total hematuria, which may be accompanied by dysuria, pollakiuria, or fever ${ }^{(1)}$. Late manifestations (chronic schistosomiasis), in addition to hematuria, include proteinuria (many times as nephrotic manifestation), calcifications, renal cramps, hydronephrosis, urethral obstruction, renalfailure and, possibly, bladder neoplasm (4). Less frequently, there is the formation of immune complexes that contain specific parasite antigens that when deposited on the glomerular capillaries induce schistosomic glomerulopathy of variable degree. This renal impairment is frequent in infestation by Schistosoma mansonii and the most severe forms of the disease (glomerulonephritis grades III and IV) are normally associated with hepatic-splenic involvement and progress to chronic renal failure ${ }^{(9)}$.

The definite diagnosis of urinary schistosomiasis is made by identification of eggs in the urine or bladder biopsies. Considering that egg elimination is constant during the whole day, it is recommended the collection of three urine samples between $10 \mathrm{am}$ and $2 \mathrm{pm}$ (greater excretion period) or after physical exercise ${ }^{(2)}$. Serological studies for schistosoma are equally useful in the diagnosis, but they do not differentiate previous from recent infection. Renal and vesical echographies are non-invasive tests that enable detection of advanced disease. In an initial stage, cystoscopy normally reveals granuloma and mucosa congestion, and later it shows sandy patches (rugous areas of vesical mucosa involving the egg deposits) ${ }^{(10)}$.

In the chronic stages, egg elimination in the urine is significantly lower and it may not be present, and the diagnosis is made based on radiological tests and clinical pathology of biopsied lesions ${ }^{(6)}$. Radiography of the urinary tract shows calcifications at urethral and vesical level resulting from egg laying on the mucosa (10). Excretory urography aims to identify possible complications in advanced stages, such as distal urethral stenosis and superior urinary tract dilation ${ }^{(10)}$.

The treatment of choice is praziquantel, a single dose of $40 \mathrm{mg} / \mathrm{kg}^{(8)}$. This therapy provides $80 \%$ cure rate and substantial reduction of number of parasites and egg excretion when cure is not effective ${ }^{(1,4)}$. The treatment with this antihelminthic eradicates the parasite and terminates the inflammatory response responsible for the chronic manifestations of the disease ${ }^{(5)}$.

In the reported case, the patient had monosymptomatic macroscopic hematuria with moderate proteinuria and previous episodes of generalized poorly characterized edema. Despite the fact that the investigation of Schistosoma eggs in the urine was positive, since a more complicated disease was suspected of, it was decided to use cytoscopy and renal biopsy as well. The histology abnormalities 
found - segmental focal glomerulosclerosis - are not normally associated with infestation by Schistosoma haematobium and they do not seem to respond to antiparasitic or immunosuppressant therapy, such as in this case. Moreover, the patient did not present liver or renal disease, which is normally associated with this type of glomerulopathy. However, the clinical resolution of the edema and the elimination of proteinuria, with no other therapy than praziquantel, seemed to confirm the diagnosis of schistosoma glomerulopathy. Considering the favorable progression (maintained after 6 months), the renal biopsy was not repeated.

The report of this clinical case aimed to build awareness of healthcare professionals who work with children coming from the African continent because it is a rare cause of hematuria in Portugal, but if it is diagnosed and treated immediately, chronic manifestations may be prevented, reducing urinary symptoms that lead to high morbidity and mortality, especially severe complications, such as renal failure and bladder neoplasm.

\section{REFERENCES}

1. Ross AG, Bartley PB, Sleigh AC, Olds GR, YueshengL, Williams GM, et al. Schistosomiasis. N Engl J Med. 2002;346(16):1212-20.

2. Gryseels B, Polman K, Clerinx J, Kestens L. Human schistosomiasis. Lancet. 2006;368(9541):1106-18.

3. Samuel M, Misra D, Larchever V, Price E. Schistosoma haematobium infection in children in Britain. BJU International. 2000;85(3):316-8.

4. Moudugil A, Kosut J. Urinary schistosomosis: an uncommon cause of gross hematuria in the industrialized countries. Pediatr Nephrol. 2007;22(8):1225-7.

5. Summer A, Staufer W, Marouschek SR, Nevins TE. Hematuria in children due to Schistosomiasis in a nonendemic setting. Clin Pediatrics (Phila). 2006;45(2):177-81.

6. Huerta L, Alacalá J, Lecumberri SN, Dorronsoro MG, Piédrola JIP. Bilharziasis: presentación de un caso clínico. Arch Esp Urol. 2007;60(7):795-9.

7. Murinello A, Gonçalves A, Loureiro C, van-Dunen F, Alvarenga J, Campos C, et al. Schistosomíase - aspectos clínicos e histo-patológicos da doença. Rev Gastrenterol Cir. 1998;15(76):53-69.

8. Danso-Appiah A, Utzinger J, Liu J, Olliaro P. Drugs for treating urinary schistosomiasis. Cochrane Database Syst Rev. 2008;(3):CD000053.

9. Barsoum RS. Schistosomiasis and the kidney. Semin Nephrol. 2003;23(1):34-41.

10. Moreno MJ, Pastor Navarro H, Giménez Bachs JM, Carrión López P, Segura Martín M, Salinas Sánchez AS, et al. Esquistosomiasis vesical, aportación de un caso y revisión de la literatura española. Actas Urol Esp. 2006;30(7):714-9. 